\title{
EGG STORAGE OF Podisus nigrispinus (HEMIPTERA: PENTATOMIDAE) PREDATORS AT LOW TEMPERATURES ${ }^{1}$
}

\author{
Victor Hugo Duarte da Costa², Marcus Alvarenga Soares ${ }^{3 *}$, Sebastião Lourenço de Assis Júnior ${ }^{4}$, Rodrigo \\ Diniz Silveira ${ }^{5}$ Tatiane Carla Reis ${ }^{6}$ and Evaldo Martins Pires ${ }^{7}$
}

\footnotetext{
${ }^{1}$ Received on 03.09.2013 accepted for publication on 21.09.2016.

${ }^{2}$ Universidade Federal dos Vales do Jequitinhonha e Mucuri, Graduação em Agronomia, Diamantina, MG - Brasil. E-mail: $<$ victorhugode@yahoo.com.br>.

${ }^{3}$ Universidade Federal dos Vales do Jequitinhonha e Mucuri, Departamento de Agronomia, Diamantina, MG - Brasil. E-mail: <marcusasoares@yahoo.com.br>.

${ }^{4}$ Universidade Federal dos Vales do Jequitinhonha e Mucuri, Departamento de Engenharia Florestal, Diamantina, MG - Brasil. E-mail:<assisjr_ento@yahoo.com>.

${ }^{5}$ Universidade Federal dos Vales do Jequitinhonha e Mucuri, Departamento de Zootecnia, Diamantina, MG - Brasil. E-mail: $<$ rodrigo-ufvjm@hotmail.com>.

${ }^{6}$ Universidade Federal dos Vales do Jequitinhonha e Mucuri, Programa de Pós-Graduação em Produção Vegetal, Diamantina, MG - Brasil. E-mail: <tatianecarlareis@yahoo.com.br>.

${ }^{7}$ Universidade Federal de Mato Grosso, Campus Universitário de Sinop, Sinop, Mato Grosso - Brasil. E-mail: <evaldo@ufmt.br>. *Corresponding author.
}

\begin{abstract}
Podisus nigrispinus are bedbug predators that are used as biological control agents of defoliating larvae in eucalypt plantations. The mass rearing of natural enemies produces large numbers of insects, but the number of predators produced may not coincide with the timing of the outbreaks of pest populations in the field. The aim of this study was to evaluate the effects of different storage periods on the eggs of $P$. nigrispinus at low temperatures of 5,13 and $15^{\circ} \mathrm{C}$. The treatments consisted of periods of $5,10,15$ and 20 days of storage of predator eggs at each temperature indicated. After the different periods of storage, the eggs were removed, and the egg viability, the survival and duration of nymphal instars and the sex ratio of emerged adults were evaluated. Egg storage at $5^{\circ} \mathrm{C}$ reduced the percentage of hatched eggs, while viability values close to $50 \%$ were observed for storage periods of up to 10 days at $13^{\circ} \mathrm{C}$ and up to 15 days at $15^{\circ} \mathrm{C}$. For these treatments, the survival rates of nymphs were similar to those of the control. The different storage periods had no effect on the duration of the nymphal stage or the sex ratio of $P$. nigrispinus at any of the temperatures. Therefore, the storage temperature of $5^{\circ} \mathrm{C}$ caused the death of the majority of the embryos, while it is possible to store P. nigrispinus eggs up to 10 and 15 days at 13 and $15^{\circ} \mathrm{C}$, respectively.
\end{abstract}

Keywords: Biological control; Mass rearing; Cold storage.

\section{ARMAZENAMENTO DE OVOS DO PREDADOR Podisus nigrispinus (HEMIPTERA: PENTATOMIDAE) EM BAIXAS TEMPERATURAS}

RESUMO-Podisus nigrispinus (Dallas) (Hemiptera: Pentatomidae) são percevejos predadores utilizados como agentes de controle biológico de lagartas desfolhadoras em florestas de eucalipto. Criações massais de inimigos naturais produzem grande número de insetos, mas o número de predadores produzidos pode não coincidir com a época de surtos populacionais de pragas no campo. O objetivo deste trabalho foi avaliar o efeito de diferentes periodos de armazenamento em ovos de P. nigrispinus em baixas temperaturas $\left(5^{\circ} \mathrm{C}, 13{ }^{\circ} \mathrm{Ce} 15\right.$ ${ }^{\circ} \mathrm{C}$ ). Os tratamentos consistiram dos períodos de armazenamento (cinco, 10, 15 e 20 dias) dos ovos do predador nas temperaturas indicadas. Após os periodos de armazenagem, os ovos foram retirados e avaliados os parâmetros: viabilidade dos ovos, sobrevivência e duração do estádio ninfal e razão sexual dos adultos emergidos. Os períodos de armazenamento de ovos $a 5^{\circ} \mathrm{C} \mathrm{reduziram} \mathrm{a} \mathrm{porcentagem} \mathrm{de} \mathrm{ninfas} \mathrm{eclodidas} \mathrm{inviabilizando} \mathrm{a} \mathrm{maioria} \mathrm{dos}$ ovos. Enquanto valores de viabilidade próximos a $50 \%$ foram observados para os periodos de armazenamento de até 10 dias para $13{ }^{\circ} \mathrm{C}$ e 15 dias armazenados a $15^{\circ} \mathrm{C}$, com taxas de sobrevivência de ninfas, similares às do controle. Não houve efeito na duração do estágio ninfal e na razão sexual de P. nigrispinus nos tratamentos 
em cada uma das temperaturas. Portanto, conclui-se que a temperatura de armazenamento de $5{ }^{\circ} \mathrm{C}$ é altamente prejudicial e inviabilizou a maioria dos embriões, enquanto a $13{ }^{\circ} \mathrm{Ce} 15^{\circ} \mathrm{C}$ é possível armazenar ovos de P. nigrispinus por até 10 e 15 dias, respectivamente.

Palavras chave: Controle biológico; Criação massal; Armazenamento a frio.

\section{INTRODUCTION}

Eucalyptus species have been used in large areas undergoing reforestation in Brazil over the past 40 years, and the productivity of these areas is mainly due to the use of clones. However, these homogeneous areas are vulnerable to insect pests (ZANUNCIO et al., 2003, 2005). Among eucalyptus pests, defoliating larvae are particularly important, with a large number of incidents species such as Eupseudosoma involuta (Sepp) (Lepidoptera: Arctiidae), Euselasia eucerus (Hewitson) (Lepidoptera: Riodinidae), Hylesia sp. Hübner (Lepidoptera: Hemileucidae), Automeris spp., Eacles imperialis (Drury) (Saturniidae), Thyrinteina arnobia (Stoll), Thyrinteina leucoceraea (Rindge), Oxydia vesulia Cramer and Sabulodes caberata Guenée (Lepidoptera: Geometridae), (PEREIRA et al., 2008, 2009; SOARES et al., 2009a).

Podisus nigrispinus predators are used for the biological control of defoliating larvae in eucalypt forests (PIRES et al., 2006, 2015; SOARES et al., 2009b). Therefore, it is necessary to improve mass rearing techniques for this natural enemy for its release into areas with larval outbreaks (LACERDA et al., 2004).

Mass rearing in the laboratory produces large numbers of natural enemies, but the produced predators may not coincide with the timing of pest outbreaks in the field. Therefore, it becomes necessary to develop techniques for the storage of biological control agents to reduce rearing costs and to increase the availability of predators in sufficient quantities and at specific times of the year.

The viability of the storage of mass-reared parasitoids has been investigated in previous studies. The parasitism rate of Trichogramma ostriniae (Pang et Chen) (Hymenoptera: Trichogrammatidae) was generally similar to that of the control after two and four weeks when stored at $9^{\circ} \mathrm{C}$ and $12^{\circ} \mathrm{C}$ but declined when storage was greater than four weeks (PITCHER et al., 2002). Riptortus pedestris (F.) (Hemiptera: Alydidae) eggs maintained at a temperature of at least $2{ }^{\circ} \mathrm{C}$ experienced less parasitism (34\%) by Ooencyrtus nezarae Ishii (Hymenoptera: Encyrtidae) than eggs maintained under natural conditions (62\%) (ALIM and LIM, 2011). Storage at $4 \pm 1^{\circ} \mathrm{C}$ reduced the fecundity and longevity of females of the parasitoids Trichogramma brassicae $(=T$. maidis n. sp.), T. cacoeciae and T. evanescens (Hymenoptera: Trichogrammatidae) (ÖZDER, 2008). However, the effects of storage at low temperatures on predators are not well known, especially in the tropics, and studies to determine the optimal temperature and storage period are required.

The objective of this research was to test the effects of different storage periods on Podisus nigrispinus (Hemiptera: Pentatomidae) eggs at low temperatures.

\section{MATERIALS AND METHODS}

This experiment was conducted at the Biological Control Laboratory of "Universidade Federal dos Vales do Jequitinhonha e Mucuri" in Diamantina, Minas Gerais State, Brazil.

The insects used were obtained from mass rearing at the laboratory where the experiment was conducted. For this study, 450 newly oviposited $P$. nigrispinus eggs $(<24 \mathrm{~h})$ were collected at random, of which 120 were stored at $5^{\circ} \mathrm{C}$, and the same quantities were stored at 13 and $15 \pm 1{ }^{\circ} \mathrm{C}$. All eggs were kept at $70 \pm 10 \%$ relative humidity in B.O.D chambers. The treatments consisted of different predator egg storage periods at each of the temperatures, with 30 eggs that were not stored (control; T1) and were kept at $25 \pm 1^{\circ} \mathrm{C} ; 30$ eggs stored for five days (T2), another 30 stored for 10 days (T3), 30 eggs stored for 15 days (T4) and 30 eggs stored for 20 days (T5). A control treatment for each of the temperatures was maintained. The $P$. nigrispinus eggs remained in Petri dishes wrapped with foil during the storage period to completely prevent the passage of light.

The 20-day storage treatment was the first to be established, and the control was the last. This allowed all treatments to be evaluated on the same day after storage. The eggs of the predator were later placed in Petri dishes $($ diameter $=15 \mathrm{~cm}$, height $=1.2 \mathrm{~cm})$, which were kept in an acclimatized room at a temperature 
of $25 \pm 1^{\circ} \mathrm{C}$, a relative humidity of $70 \pm 10 \%$ and a photoperiod of $12 \mathrm{~h}$ to allow the nymphs to hatch.

After the predator nymphs hatched, they were kept in Petri dishes until the second instar, when they were separated into groups of 10 nymphs per dish. The nymphs were fed with Tenebrio molitor Linnaeus (Coleoptera: Tenebrionidae) pupae ad libitum and were given distilled water supplied on soaked cotton balls (MENEZES et al, 2012).

The viability of eggs, the survival of individuals during the nymphal stage, the duration of the nymphal stage and the sex ratio of the P. nigrispinus adults that had emerged were determined according to treatment.

The experimental design was completely randomized. The data were submitted to regression analysis. Polynomial regression curves were generated for egg viability and the duration of the nymphal stage. The Kaplan-Meier estimator was used to create survival curves for the nymphal stage of the predator. The sex ratio was calculated by the equation $\mathrm{rs}=$ number of females / (number of females + number of males) (PASTORI et al., 2012).

\section{RESULTS}

At the temperature of $5^{\circ} \mathrm{C}, 3.3 \%$ of nymphs hatched on the fifth day of storage, and no nymphs were observed in the other treatments. At $13^{\circ} \mathrm{C}, 63.3,46.7$, 70 and $33 \%$ of nymphs hatched, respectively, for the control and five, 10 and 15 days of storage, and no $P$. nigrispinus hatched for the 20-day storage treatment. At $15^{\circ} \mathrm{C}$, the rates were $73.3 \%, 43.3 \%, 46.7 \%, 56.6 \%$ and $6.7 \%$ for the control and five, 10,15 and 20 days of storage, respectively. A strong slope in the quadratic polynomial regression curve was observed during incubation at $13^{\circ} \mathrm{C},\left(\right.$ Figure 1 ), whereas for the $15^{\circ} \mathrm{C}$ treatment, a cubic polynomial regression curve was obtained (Figure 2).

Nymph survival rates of 53, 43 and $67 \%$ were observed for the control and five and 10 days when stored at $13^{\circ} \mathrm{C}$; nymphal survival could not be calculated for the other treatments (15 and 20 days) because none of the individuals lived to adulthood. In the treatments at $15^{\circ} \mathrm{C}$, the observed survival was 86,92 , $100,82.3$ and $50 \%$ for the control and five, 10,15 and 20 days of storage, respectively.

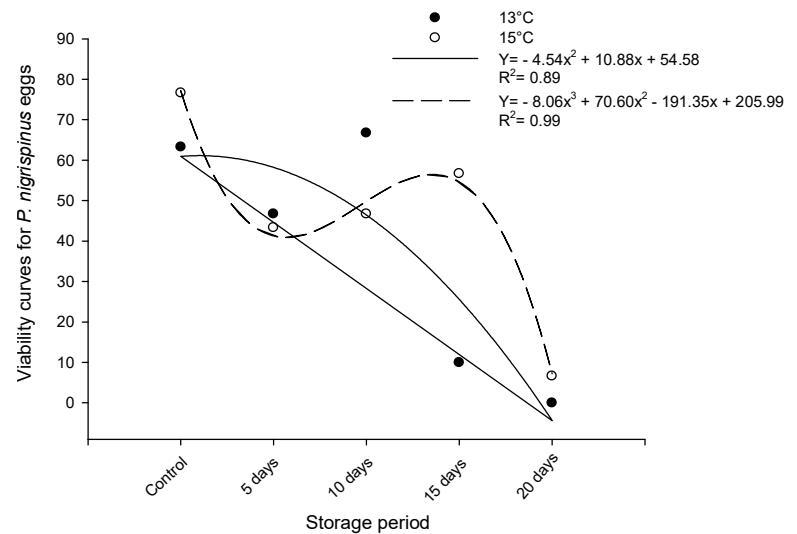

Figure 1 - Viability curves for Podisus nigrispinus eggs without storage (control; T1) or stored in a B.O.D. chamber at $13^{\circ} \mathrm{C}$ and $15^{\circ} \mathrm{C}\left( \pm 1{ }^{\circ} \mathrm{C}\right)$ for five (T2), $10(\mathrm{~T} 3)$, 15 (T4) and 20 (T5) consecutive days.

Figura 1 - Curvas de regressão para a viabilidade de ovos de Podisus nigrispinus sem armazenamento controle (T1), ou armazenados em estufa B.O.D a $13{ }^{\circ} \mathrm{Ce} 15^{\circ} \mathrm{C}\left( \pm 1{ }^{\circ} \mathrm{C}\right)$, por cinco (T2), $10(\mathrm{~T} 3)$, 15 (T4) e 20 (T5) dias consecutivos.

In the treatments maintained at $5^{\circ} \mathrm{C}$, no insects were obtained to evaluate the mean duration of the nymphal stage. For the treatments at $13^{\circ} \mathrm{C}$, the average duration was 25.2 days for the control and 23.2 and 19.4 days for five and 20 days, respectively, but no surviving insects were obtained for the 15-day storage treatment. For the treatments stored at $15^{\circ} \mathrm{C}$, the averages were 24.3 for five, 23.4 for 10,22 for 15 and 21.4 for 20 days of storage. After hatching, and regardless of temperature and storage period, a linear regression curve was observed for nymphal development, with a slight increase with the duration of the tested periods (Figure 3).

Sex ratios were not calculated for the treatments under the temperature of $5^{\circ} \mathrm{C}$ due to the lack of live insects reaching adulthood, making it not possible to analyze this parameter. For the treatments at $13{ }^{\circ} \mathrm{C}$, the sex ratio already showed similar results to the control at 10 days of storage, with values of 0.38 for no storage and 0.20 and 0.33 for five and 10 days of storage, respectively, but there was no adult emergence for the 15-and 20-day storage treatments. For the treatments at $15^{\circ} \mathrm{C}$, a value of 0.53 was obtained for the control, and $0.42,1.00$, and 0.64 were obtained for five, 10 and 15 days of storage, but no adult emergence occurred for the 20-day storage treatment.

Revista Árvore, Viçosa-MG, v.40, n.5, p.877-884, 2016 

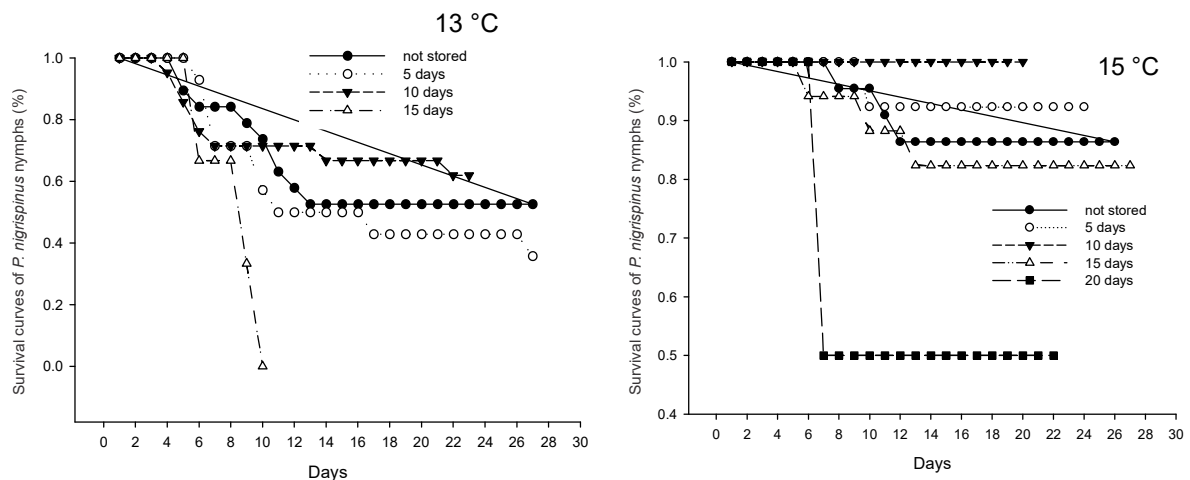

Figure 2 - Survival curves obtained with the Kaplan-Meier estimator for Podisus nigrispinus nymphs from eggs that were not stored and after storing eggs in a B.O.D. chamber at $13^{\circ} \mathrm{C}$ and $15^{\circ} \mathrm{C}\left( \pm 1^{\circ} \mathrm{C}\right)$ for five, 10,15 and 20 consecutive days. Diamantina, Minas Gerais, Brazil.

Figura 2 - Curvas de sobrevivência obtidas com o estimador Kaplan-Meier, de ninfas de Podisus nigrispinus após armazenamento de ovos em estufa B.O.D a $13{ }^{\circ} \mathrm{Ce} 15^{\circ} \mathrm{C}\left( \pm 1^{\circ} \mathrm{C}\right)$ sem armazenamento, e por cinco, 10,15 e 20 dias consecutivos. Diamantina, Minas Gerais, Brasil.

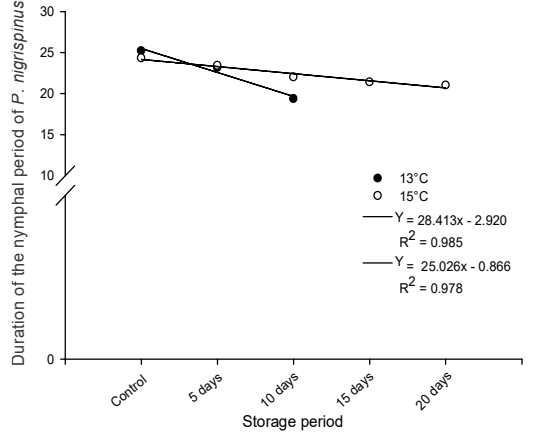

Figure 3-Regression curves for the duration of the nymphal period of Podisus nigrispinus without storage (T1) or stored in a B.O.D. chamber at $13^{\circ} \mathrm{C}$ and $15^{\circ} \mathrm{C}$ $\left( \pm 1{ }^{\circ} \mathrm{C}\right)$ for five (T2), $10(\mathrm{~T} 3), 15(\mathrm{~T} 4)$ and 20 (T5) consecutive days.

Figura 3 - Curvas de regressão para a duração ninfal de Podisus nigrispinus (dias), sem armazenamento (T1), ou armazenados em estufa B.O.D a $13{ }^{\circ} \mathrm{C}$ e $15^{\circ} \mathrm{C}\left( \pm 1{ }^{\circ} \mathrm{C}\right)$ por cinco (T2), 10 (T3), 15 (T4) e 20 (T5) dias consecutivos.

\section{DISCUSSION}

Different periods of storage of predator eggs were tested at low temperatures $\left(5,13\right.$ and $\left.15^{\circ} \mathrm{C}\right)$, and the results may lead to new insights in the methods for rearing this predator in the laboratory. Significant results were obtained when comparing the viability of eggs stored at different temperatures. The percentage of nymphs that hatched at $5^{\circ} \mathrm{C}$ was adversely affected by this temperature. Other studies corroborate these observations, reporting the same consequences for Coccinella undecimpunctata (Linnaeus) (Coleoptera: Chrysopidae) eggs stored at $7^{\circ} \mathrm{C}$ or Anastrepha ludens (Loew) (Diptera: Tephritidae) eggs stored at $-3^{\circ} \mathrm{C}$ (ABDELSALAM; ABDEL-BAKY, 2000; ALUJA et al., 2008).

The inviability of most eggs stored at $5^{\circ} \mathrm{C}$ for the tested storage periods most likely occurs from the death of $P$. nigrispinus embryos. The exposure to cold can trigger injuries that can be expressed in lethal or sublethal effects (HANCE et al., 2007). In this context, the temperature of $5^{\circ} \mathrm{C}$ was lethal for P. nigrispinus and should therefore not be suggested in programs aimed at increasing the lifetime of these natural enemies in mass rearing.

At $13^{\circ} \mathrm{C}$, the strong slope of the regression curve shows lower viability of the predator eggs with increases in the storage period. However, there was no decline in the curve for up to 10 days of storage, with observed viability values near $50 \%$, which had also been observed by Jackson et al. (1995) in Diabrotica undecimpunctata, (Barber) (Coleoptera: Chrysomelidae), by Lacey et al., (1999) in Bemisia argentifolii (Bellows \& Perring) (Hemiptera: Aleyrodidae) and by Fisher and Edwards (2002) in Otiorhynchus ovatus (Linnaeus) (Coleoptera: Curculionidae). Thus, these results show that it is possible to store the predator eggs at $13^{\circ} \mathrm{C}$ for up to 10 days without significant loss in viability.

In the treatments performed at $15^{\circ} \mathrm{C}$, from five days of storage up to 15 days, the egg viability curve ranged 
from values of approximately $50 \%$ and, therefore, this temperature can also be recommended for storing the predator eggs. Low temperatures, up to a certain limit, and the time of exposure may cause a reduction in the metabolic rate, inducing insects to enter dormancy. This makes it possible to store natural enemies under laboratory conditions without a loss of biological characteristics, allowing the insects to complete normal development when exposure to cold is discontinued (VENTURA et al., 2002; HODKOVA; HODEK, 2004). This pattern was observed for periods of up to 10 days of storage at $13^{\circ} \mathrm{C}$ and up to 15 days at $15^{\circ} \mathrm{C}$, indicating that the eggs entered dormancy, completing their normal development after terminated disturbance without a large loss of viability.

Storage at low temperatures for more than two weeks is a key factor in the successful development of mass rearing and augmentative methods of biological control (OSMAN and SELMAN, 1993). Using this technique, it is possible to provide greater numbers of individuals during periods when population outbreaks of pests occur in the field (ABDEL-SALAN and ABDELBAKY, 2000). With the delays in the development of $P$. nigrispinus of up to 10 and 15 days obtained in the posture cultures maintained at 13 and $15^{\circ} \mathrm{C}$, respectively, it would be possible to time the release of a greater number of natural enemies in the field during specific periods.

The dose of cold exposure is the combination of the duration of exposure and the temperature. When the temperature decreases or the exposure time increases, greater exposure doses can be obtained. Because this is a cumulative factor, a higher exposure to cold most likely increases damage, and insect death is the ultimate effect of such disturbance (KOSTAL et al., 2004). This was observed for eggs stored for over 10 days at $13^{\circ} \mathrm{C}$ and those stored for 20 days at $15^{\circ} \mathrm{C}$, where the responses to cold exposure are cumulative. Thus, the increase in storage periods led to damage causing the inviability of most of the eggs (SLACHTA et al., 2002).

Rates of nymph survival that were similar to those of the control were observed in the periods of up to 10 days of storage at $13^{\circ} \mathrm{C}$ and 15 days at $15^{\circ} \mathrm{C}$. A similar result was observed for Graphosoma lineatum (Linnaeus) (Hemiptera: Pentatomidae) (SLACHTA et al., 2002).

Organisms exposed to cold for prolonged periods severely deplete their energy reserves. Insect embryos direct energy from vitellogenic reserves to maintenance and development (SOARES et al., 2011). When subjected to low temperatures, these individuals use these energy reserves to survive under cold stress. This reallocation of resources prevents insects from completing their development and can lead to death (RENAULT et al., 2003). This was observed in P. nigrispinus under long storage periods when maintained at $13^{\circ} \mathrm{C}$ or $15^{\circ} \mathrm{C}$, verifying that the hatched individuals did not have enough energy to complete their development and reach adulthood.

Changes in the duration of the nymphal stage can be critical in the success of the use of storage techniques at low temperatures in biological control programs (COLINET; BOIVIN, 2011). Such changes were reported for the predator Podisus maculiventris (Say) (Hemiptera: Pentatomidae), showing that the duration of the nymphal stage increased significantly when the eggs were stored for extended periods of time (one month) at $9^{\circ} \mathrm{C}$ (DECLERCQ; DEGHEELE, 1993). The maintenance of development characteristics after storage is essential for insect survival in the field, allowing them to maintain their normal development and reach the reproductive phase quickly. Thus, egg storage at $13^{\circ} \mathrm{C}$ and $15^{\circ} \mathrm{C}$ for up to 10 and 15 days, respectively, can succeed because insect development did not change under these conditions.

Exposure to cold may be expressed differently in males and females of the same species. The results of other studies show such differences, with males of Aphidius rhopalosiphi (De Stephani Perez) (Hymenoptera: Braconidae) exhibiting a greater sensitivity to cold and negative effects occurring in females of Gonatocerus ashmeadi (Girault) (Hymenoptera: Mymaridae)(CHEN etal., 2008; BOURDAIS et al., 2012). This was not shown for P. nigrispinus, as both males and females emerged after storage.

\section{CONCLUSION}

The storage of $P$. nigrispinus eggs at $5^{\circ} \mathrm{C}$ can disrupt embryo development, suggesting that this temperature should be avoided in maintaining the eggs of this predator. At temperatures of 13 and $15^{\circ} \mathrm{C}$, it is possible to store the predator eggs for up to 10 and 15 days, respectively, without degradation in the performance of the hatched nymphs. These temperatures and storage times are the most suitable for use in the mass rearing of this natural enemy for the development of biological control programs against pests.

Revista Árvore, Viçosa-MG, v.40, n.5, p.877-884, 2016

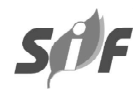




\section{ACKNOWLEDGMENTS}

To Conselho Nacional de Desenvolvimento Científico e Tecnológico (CNPq), to the Coordenação de Aperfeiçoamento de Pessoal de Nível Superior (CAPES) and Fundação de Amparo à Pesquisa do Estado de Minas Gerais (FAPEMIG) for financial support.

\section{REFERENCES}

ABDEL-SALAM, A.H.; ABDEL-BAKY, N.F. Possible storage of Conccinella undecimpunctata (Coleoptera: Coccinellidae) under low temperature and its effect on some biological characteristics. Journal of Applied Entomology, v. 124, n.3-4, p.169$176,2000$.

ALIM, M.A.; LIM, U.T. Regrigerated eggs of Riptortus pedestris (Hemiptera: Alydidae) added to aggregation pheromone traps increase field parasitism in soybean. Journal of Economic Entomology, v.104, n.6, p.18331839,2011

ALUJA, M.; DÍAZ-FLEISCHER, F.; ARREDONDO, J.; VALLE-MORA, J.; RULL. Effect of cold storage on larval and adult Anastrepha ludens (Diptera: Tephritidae) viability in commercially ripe, artificially infested Persea american 'Hass'. Journal of Economic Entomology, v.103, n.6, p.200, 2008.

BOURDAIS, D.; VERNON, P.; KRESPI, L.; VAN BAAREN, J. Behavioural consequences of cold exposure on males and females of Aphidius rhopalosiphi (De Stephani Perez) (Hymenoptera: Braconidae). BioControl, v.57, n.3, p.349-360, 2012.

CHEN, W.L.; LEOPOLD, R.A.; HARRIS, M.O. Cold storage effects on maternal and progeny quality of Gonatocerus ashmeadi Girault (Hymenoptera: Mymaridae). Biological Control, v.4, n.2, p.122-132, 2008.

COLINET, H.; BOIVIN, G. Insect parasitoids cold storage: A comprehensive review of factors of variabilityand consequences. Biological Control, v.58, n.2, p.83-95, 2011.

DE CLERCQ, P.; DEGHEELE, D. Cold storage of the predatory bugs Podisus maculiventris (Say) and Podisus sagitta (Fabricius) (Heteroptera: Pentatomidae). Parasitica, v.49, v.27-41, 1993.

FISHER, J.R.; EDWARDS, D.L. Temperaturedependent egg hatch and cold storage ofeggs of Otiorhynchus ovatus (Lin.) (Coleoptera:

Curculionidae). Journal of Agricultural and Urban Entomology, v.19, p.109-116, 2002.

HANCE, T. et al. Impact of extreme temperatures on parasitoids in a climate change perspective. Annual Review of Entomology, v.52, p.107-126, 2007.

HODKOVA, M.; HODEK, I. Photoperiod, diapause and cold-hardiness. European Journal of Entomology, v.101, p.445-458, 2004.

JACKSON, J.J.; LEW, A.C.; WOODSON, W.D. Effect of egg age, storage temperature, and storage duration on egg hatch of Diabrotica undecimpunctata Howardi (Coleoptera:

Chrysomelidae). Annals of the

Entomological Society of America, v.88, n.6, p.781-784, 1995.

KOSTAL, V.; VAMBERA, J.; BASTL, J. On the nature of pre-freeze mortality in insects: water balance, ion homeostasis and energy charge in the adults of Pyrrhocoris apterus. Journal of Experimental Biology, v.207, n.9, p.1509. 1521, 2004.

LACERDA, M.C.; FERREIRA, A.M.R.M.; ZANUNCIO, T.V.; ZANUNCIO, J.C.;

BERNARDINO, A.S.; ESPINDULA, M.C. Development and reproduction of Podisus distinctus (Heteroptera: Pentatomidae) fed on larva of Bombyx mori (Lepidoptera: Bombycidae). Brazilian Journal Biology, v.64, n.2, p.237242, 2004

LACEY, L.A.; MILLAR, L.; KIRK, A.A.; PERRING, T.M. Effect of storage temperature and duration on survival of eggs and nymphs of Bemisia argentifolii (Homoptera: Aleyrodidae) and pupae of the whitefly parasitoid Encarsia formosa (Hymenoptera:

Aphelinidae). Annals of the Entomological Society of America, v.92, n.3, p.430-434, 1999.

MENEZES, C.W.G.; SANTOS, J.B.; ASSIS

JÚNIOR, S.L.; FONSECA, A.J.; FRANÇA, A.C.; 
SOARES, M.A.; FERNANDES, A.F. Seletividade de atrazine e nicossulfurom a Podisus nigrispinus (Heteroptera: Pentatomidae). Planta Daninha, v.30, n.2, p.327-334, 2012.

OSMAN, M.Z.; SELMAN, B.J. Storage of Chrysoperla carnea (De Stephani Perez) (Neuroptera: Chrysopidae) eggs and pupae. Journal of Applied Entomology, v.115, p.420-424, 1993.

ÖZDER, N. Effect of cold storage of adult Trichogramma brassicae, T. cacoeciae and $T$. evanescens (Hym.: Trichogrammatidae).

Archives of Phytopathology and Plant Protection, v.41, n.4, p.296-299, 2008.

PASTORI, P.L.; PEREIRA, F.F.; ANDRADE, G.S.; SILVA, R.O.; ZANUNCIO, J.C.; PEREIRA, A.Í.A. Reproduction of Trichospilus diatraeae (Hymenoptera: Eulophidae) in pupae of two lepidopterans defoliators of eucalypt. Revista Colombiana de Entomologia, v. 38, n.1, p.91-93, 2012.

PEREIRA, F.F.; ZANUNCIO, T.V.; ZANUNCIO, J.C.; PRATISSOLI, D.; TAVARES, M.T. Species of Lepidoptera defoliators of Eucalyptus as new host for the parasitoid Palmistichus elaeisis (Hymenoptera: Eulophidae). Brazilian Archives of Biology and Technology, v.51, n.2, p.259-262, 2008.

PEREIRA, F.F.; ZANUNCIO, J.C.; SERRÃO, J.E.; PASTORI, P.L.; RAMALHO, F.S. Reproductive performance of Palmistichus elaesis (Hymenoptera: Eulophidae) with previously refrigerated pupae of Bombyx mori (Lepidoptera: Bombycidae). Brazilian Journal of Biology, v.69, n.1, p.865-869, 2009.

PIRES, E.M.; PINTO, R.; LACERDA, M.C., ZANUNCIO, J.C.; FIALHO, M.C.Q. Potencial reprodutivo horário do predador de lagartas desfolhadoras do eucalipto: Podisus nigrispinus (Heteroptera: Pentatomidae). Revista Árvore, v.30, n.6, p.1039-1044, 2006.

PIRES, E.M.; SOARES, M.A.; NOGUEIRA, R.M.; ZANUNCIO, J.C.; MOREIRA, P.S.A.; OLIVEIRA, M.A. Seven decades of studies with Asopinae predators in Brazil - (1933-2014). Bioscience Journal, v. 31, n.5, p. 1530-1549, 2015.
PITCHER, S.A. HOFFMANN, M.P. GARDNER, J.; WRIGHT, M.G.; KUHAR, T.P. Cold storage of Trichogramma ostriniae reared on Sitotroga cerealella eggs. BioControl, v.47, n.5, p.525$535,2002$.

RENAULT, D.; HANCE, T.; VANNIER, G.; VERNON, $P$. Is body size an inûuential parameter in determining the duration of survival at low temperatures in Alphitobius diaperinus Panzer (Coleoptera: Tenebrionidae)? Journal of Zoology, v.259, n.4, p.381-388, 2003.

SLACHTA, M.; VAMBERA, J.; ZAHRADNÍCKOVÁ, H.; KOSTÁL V. Entering diapause is a prerequisite for successful cold-acclimation in adult Graphosoma lineatum (Heteroptera: Pentatomidae). Journal of Insect Physiology, v.48, n.11, p.1031-1039, 2002.

SOARES, M.A.; GUTIERREZ, C.T.; ZANUNCIO, J.C.; PEDROSA, A.R.P.; LORENZON, A.S.

Superparasitismo de Palmistichus elaeisis (Hymenoptera: Eulophidae) y comportamiento de defense de los hospederos. Revista

Colombiana de Entomología, v.35, n.1, p.62-65, 2009a.

SOARES, M.A.; ZANUNCIO, J.C.; LEITE, G.L.D.; REIS, T.C.; SILVA, M.A. Controle biológico de pragas em armazenamento: uma alternativa para reduzir o uso de agrotóxicos no Brasil?

Unimontes Científica, v.11, n.1/2, p.52-59, 2009b.

SOARES, M.A.; BATISTA, J.D.; ZANUNCIO, J.C.; LINO-NETO, J.; SERRÃO, J.E. Ovary development, egg production and oviposition for mated and virgin females of the predator Podisus nigrispinus (Heteroptera: Pentatomidae). Acta Scientiarum. Agronomy, v.33, n.4, p.597-602, 2011.

VENTURA, G.P.; WAJNBERG, E.; PIZZOL, J.; OLIVEIRA, M.L. Diapause in the egg parasitoid Trichogramma cordubensis: role of temperature. Journal of Insect Physiology, v.48, n.3, p.349-355, 2002.

ZANUNCIO, J.C.; ZANUNCIO, T.V.; DE FREITAS, F.A.; PRATISSOLI, D. Population density of Lepidoptera in a plantation of Eucalyptus urophylla in the state of Minas Gerais, Brazil. Animal Biology, v.53, n.1, p.17-26, 2003.

Revista Árvore, Viçosa-MG, v.40, n.5, p.877-884, 2016

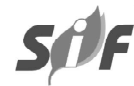


ZANUNCIO, T.V.; ZANUNCIO, J.C.; ZANUNCIO JUNIOR, J.S.; SANTOS, G.P.; FIALHO, M.C.Q.; BERNARDINO, A.S. Aspectos biológicos e morfológicos de Mimallo amilia (Lepidoptera: Mimallonidae) em folhas de Eucalyptus urophylla. Revista Árvore, v.29, n.2, p.321-326, 2005. 